\title{
Rockfall-induced impact force causing a debris flow on a volcanoclastic soil slope: a case study in southern Italy
}

\author{
P. Budetta \\ Section of Applied Geology, Department of Hydraulics, Geotechnical and Environmental Engineering, \\ University of Naples "Federico II", Piazzale Tecchio, 80, 80125 Naples, Italy
}

Received: 15 June 2010 - Revised: 27 August 2010 - Accepted: 2 September 2010 - Published: 27 September 2010

\begin{abstract}
On 10 January 2003, a rockfall of approximately $10 \mathrm{~m}^{3}$ affected a cliff some $25 \mathrm{~m}$ high located along the northern slopes of Mt. St. Angelo (Nocera Inferiore, province of Salerno) in the southern Italian region of Campania. The impact of boulders on the lower sector of the slope, along which detrital-pyroclastic soils outcrop, triggered a small channelled debris flow of about $500 \mathrm{~m}^{3}$. Fortunately, no damage nor victims resulted from the landslide. Several marks of the impacts were observed at the cliff toe and outside the collapsed area, and the volumes of some fallen boulders were subsequently measured. By means of in-situ surveys, it was possible to reconstruct the cliff's geo-structural layout in detail. A rockfall back-analysis was subsequently performed along seven critical profiles of the entire slope (surface area of about $4000 \mathrm{~m}^{2}$ ). The results of this numerical modelling using the lumped-mass method were then used to map the kinetic iso-energy curves. In the triggering area of the debris flow, for a falling boulder of $1 \mathrm{~m}^{3}$, the mean kinetic energy was estimated at $120 \mathrm{~kJ}$, this value being equivalent to an impact force, on an inclined surface, of some $800 \mathrm{kN}$. After landing, due to the locally high slope gradient $\left(\right.$ about $45^{\circ}$ ), and low angle of trajectory at impact (about $23^{\circ}$ ), some boulders slid down the slope as far as the endpoints. The maximum depth of penetration into the ground by a sliding block was estimated at about $16 \mathrm{~cm}$. Very likely, owing to the high impact force of boulders on the saturated soil slope outcropping at the cliff base, the debris flow was triggered under undrained loading conditions. Initial failure was characterized by a translational slide involving a limited, almost elliptical area where the pyroclastic cover shows greater thickness in comparison with the surrounding areas.
\end{abstract}

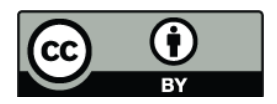

Correspondence to: P. Budetta (budetta@unina.it)

\section{Introduction}

Extensive areas of northwestern Campania (southern Italy) are affected by high landslide hazard due to debris slides/flows and debris avalanches involving pyroclastic fall and detrital-alluvial deposits, mantling very steep slopes of carbonate bedrock. About $3000 \mathrm{~km}^{2}$ of the region and some 200 villages and towns are at risk from these phenomena (De Riso et al., 2005). After the landslides that hit Sarno and Quindici on 5 May 1998, the triggering factors and possible mechanisms of instabilities were extensively analysed in the scientific literature, with the focus ranging from the geomorphology, physical and geotechnical properties of the pyroclastic materials to rainfall patterns, groundwater conditions, land use and man-made alterations (Del Prete et al., 1998; De Riso et al., 1999; Di Crescenzo and Santo, 1999; Amanti et al., 1999; Brancaccio et al., 1999; Guadagno and Perriello Zampelli, 2000; Guadagno and Magaldi, 2000; De Vita, 2000; Fiorillo et al., 2001; Budetta, 2002; Budetta and De Riso, 2004; Calcaterra et al., 2003; Crosta and Dal Negro, 2003; Guadagno et al., 2005).

Attempts to map debris-flow susceptibility in Campania through geo-morphological or geotechnical approaches, sometimes using data processing systems, are due to several authors. For instance, Di Crescenzo and Santo (2005) and Iovine et al. (2003 and 2005) used morphometric approaches or cellular automata models.

Guadagno et al. (2005) showed the results of detailed surveys of the morphological characteristics of the landslide source areas in Sarno - Quindici, demonstrating that the initial failures were probably associated with the presence of morphological discontinuities, such as limestone scarps and road cuts. Di Crescenzo and Santo (2005) studied the various geomorphological aspects of these landslides and highlighted the repetitiveness of events along road cuts and rocky scarps: about $86 \%$ of their 172 investigated landslides occurred above or below roads/tracks and cliffs.

Published by Copernicus Publications on behalf of the European Geosciences Union. 
Civita et al. (1975), Guadagno et al. (1986) and Brancaccio et al. (1999) focused on the role of rockfalls in triggering debris flows in the Mt. St. Costanzo, Palma Campania, Sarno and Siano landslides. The predisposing factor for most debris flow/slides was the presence of cliffs where rockfalls developed.

With reference to geotechnical parameters of the volcanoclastic soils, Esposito and Guadagno (1998) stressed the physical characteristics peculiar to pyroclastic deposits and related pumices; pumice particles have interconnected internal voids whose dimensions cause suction, as a consequence of which there is a complex diffusion in groundwater accumulation. In addition, the horizons derived from pyroclastic soil typically have peculiar characteristics due mainly to the presence of allophanic clays. Allophane is an amorphous hydrous aluminium silicate clay mineral, coming from hydrothermal alteration product of feldspars, and has a composition similar to kaolinite (Terribile et al., 1999; Guadagno and Magaldi, 2000). The high water retention values greatly affect the shear strength, and at saturation the matrix suction vanishes, thereby reducing cohesion almost to zero. With reference to the pyroclastic soils of northwestern Campania, Crosta and Dal Negro (2003) verified that the peak friction angle ranges between $35^{\circ}$ and $45^{\circ}$, and that the residual friction angle, which is similar to the peak angle, ranges between $31^{\circ}$ and $41^{\circ}$. Besides being caused by granulometric sorting of particles, such high values could be due to the presence of allophane. This clay does not show the platy shape characteristic of other clay particles, which excludes the reorientation of particles in shearing (Crosta and Dal Negro, 2003).

Dealing with the geotechnical properties of the soils involved in the debris flows, Olivares and Picarelli (2006) and Picarelli (2010) emphasized that slope failures are generally caused by rainfall-related water infiltration. Soil liquefaction can be caused by the rapid increase in shear stress associated with suction decrease or by other mechanisms of internal stress change, such as boulder impacts or the drop in shear strength caused by other mechanical processes. On this point, Cairo and Dente (2003) cited the case of a debris flow triggered in pyroclastic soils by the discharging of materials, resulting from excavation, pushed into a gully by a bulldozer. The dynamic disturbance due to the impact produced by throwing the material caused a rapid pore water pressure increase, reducing the shear strength of the sandysilty soils. A stability back-analysis showed that the initial effective stress of the former soil slope was such that a small increase in shear stress, under undrained conditions, was required to trigger flow liquefaction. In addition, finite element simulations revealed that the compressive strain levels induced by impact loading on the soil slope below are consistent with those required in triaxial tests on pyroclastic soil samples from the Campania region to produce liquefaction. Sassa et al. (1997) showed that the debris flow affecting Minamata City (Japan) was triggered by loading due to an initial failed slide mass that piled up on pre-existing saturated vol- canoclastic deposits, with loose and unstable structure. The rapid drop of shear resistance in these deposits was due to grain crushing and the resulting failure of the soil structure; this caused rapid excess pore pressure generation. Because the deposits were saturated, they were shared by undrained loading and transported downstream together with the overlooking sliding mass.

Similar mechanisms were also proposed by Hutchinson and Bhandari (1971) and Costa and Williams (1984). Liquefaction takes place in soils with loose meta-stable structure so long as grain crushing and the resulting volume reduction takes place under the given overburden pressure. Sassa et al. (2004) described a dynamic-loading ring-shear apparatus that can simulate the formation of shear zones including long and rapid shear displacements that occur in highvelocity or earthquake-induced landslides, under undrained loading conditions. Iverson et al. (1997) indicated that most landslides that mobilize to form debris flows are triggered by increased pore-water pressures associated with rainfall, snowmelt, or groundwater inflow from adjacent areas. If the landslide debris is saturated or nearly saturated at the time of slope failure, the potential for debris-flow mobilization is increased. Dealing with extensive deformations due to rockslides in mountain areas, Geertsema et al. (2006) suggested that the excess mobility affecting some landslide debris is due to rapid undrained loading of till by the initial rock-slide.

Although several studies have been performed regarding slope failure in volcanoclastic soils with several pore pressure boundary conditions (Crosta and Dal Negro, 2003; Cascini et al., 2005), there are few investigations concerning numerical modelling of soil collapses mainly triggered by rockfalls. Crosta (1994) showed the results of a stability analysis for a complex landslide with rockfall simulations and a distinct-element method, but the geomorphological setting of the studied area was very different from those found in Campania. The difficulty in quantifying parameters such as rockfall volumes, trajectories, impact points and kinetic energies involved greatly hampers evaluation of dynamic overloading. Indeed, the rapid collapse of the soil slope hit by boulders deletes the impact marks, hampering kinematical back-analysis of the block rebounds.

The aim of this paper is to evaluate the kinetic energies and the impact force of collapsed blocks that fell from a dolomitic-limestone cliff and landed on a gentler slope below, applying loads sufficient to trigger a debris flow. The reported case study was made possible by means of backanalysis of rockfall trajectories reconstituted on the basis of impact marks and using the most suitable normal and tangential coefficients of restitution of the investigated materials. In order to evaluate the stress caused in the pyroclastic cover, an attempt was made to calculate the impact force as a function of the kinetic energy of a block and its depth of penetration. The bottom line of the paper is to seek to establish threshold conditions, in terms of energy and depth of penetration, for triggering rockfall-induced debris flow. 


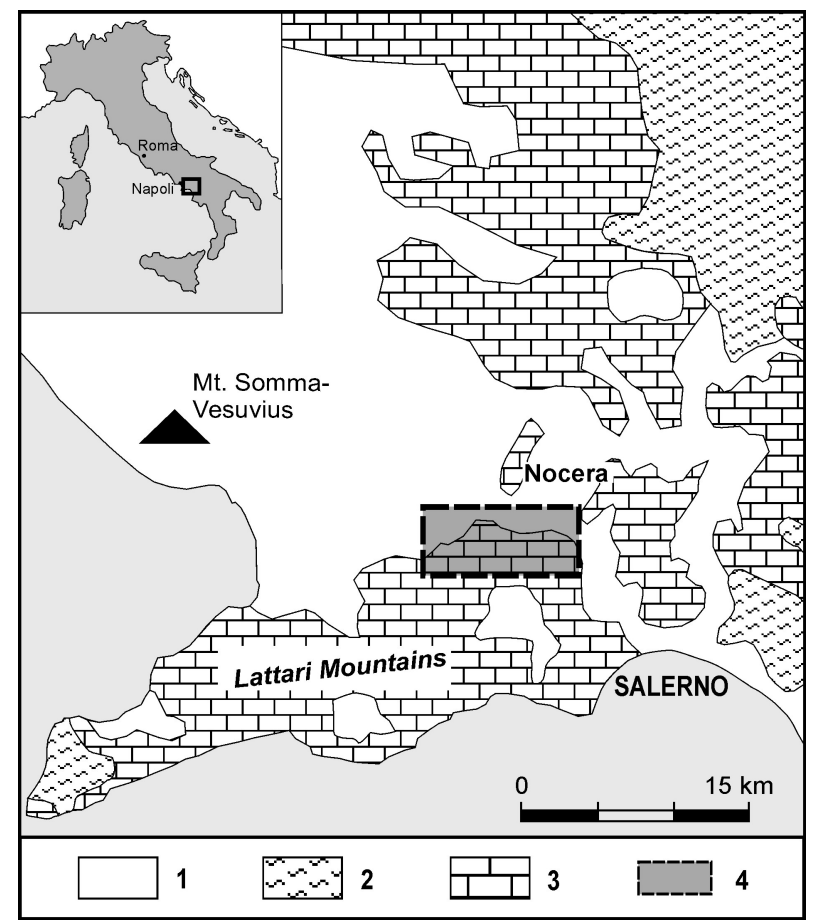

Fig. 1. Location of the study area. (1) Epiclastic and pyroclastic deposits (thickness $>10 \mathrm{~m}$ ), Holocene; (2) Flysch and silicoclastic deposits, Mesozoic - Tertiary; (3) Carbonate rocks with thin volcanoclastic deposits (thickness $<10 \mathrm{~m}$ ), Mesozoic; (4) Study area.

\section{Geomorphology of the study area}

The study area is part of the extreme northern sector of the carbonate ridge of the Sorrento Peninsula-Lattari Mountains (Fig. 1). This mountainous area is often affected by debris slides/flows and debris avalanches involving the volcanoclastic deposits mantling very steep slopes of carbonate bedrock. Such collapses can sometimes be classified as complex landslides if they are triggered during heavy rainfall by concomitant rockfalls, such as the debris flows of Mt. St. Liberatore in 1954 and Mt. St. Costanzo in 1973 (Fig. 2). The study area itself is the northern slope of Mt. St. Angelo, whose summit reaches $1130 \mathrm{~m}$ above sea level. The slope (approximately $8.5 \mathrm{~km}^{2}$ ) is an old fault scarp oriented W-E and dipping on average $37^{\circ}$ (Fig. 3). On the slope, crossbedded Mesozoic dolomitic-limestone outcrop, dipping approximately $18^{\circ} \mathrm{WNW}$, which are in turn overlain by continental detrital-alluvial and pyroclastic fall deposits. The pyroclastic deposits are a few metres thick and linked to late Pleistocene-Holocene eruptions of the Campi Flegrei and Somma-Vesuvius volcanic centres. The deposits consist of sandy-silty volcanic ashes, residual clayey soils from old volcanic ashes and pumiceous strata located at various heights in the stratigraphic sequences. The slope has a thick natural vegetation cover.
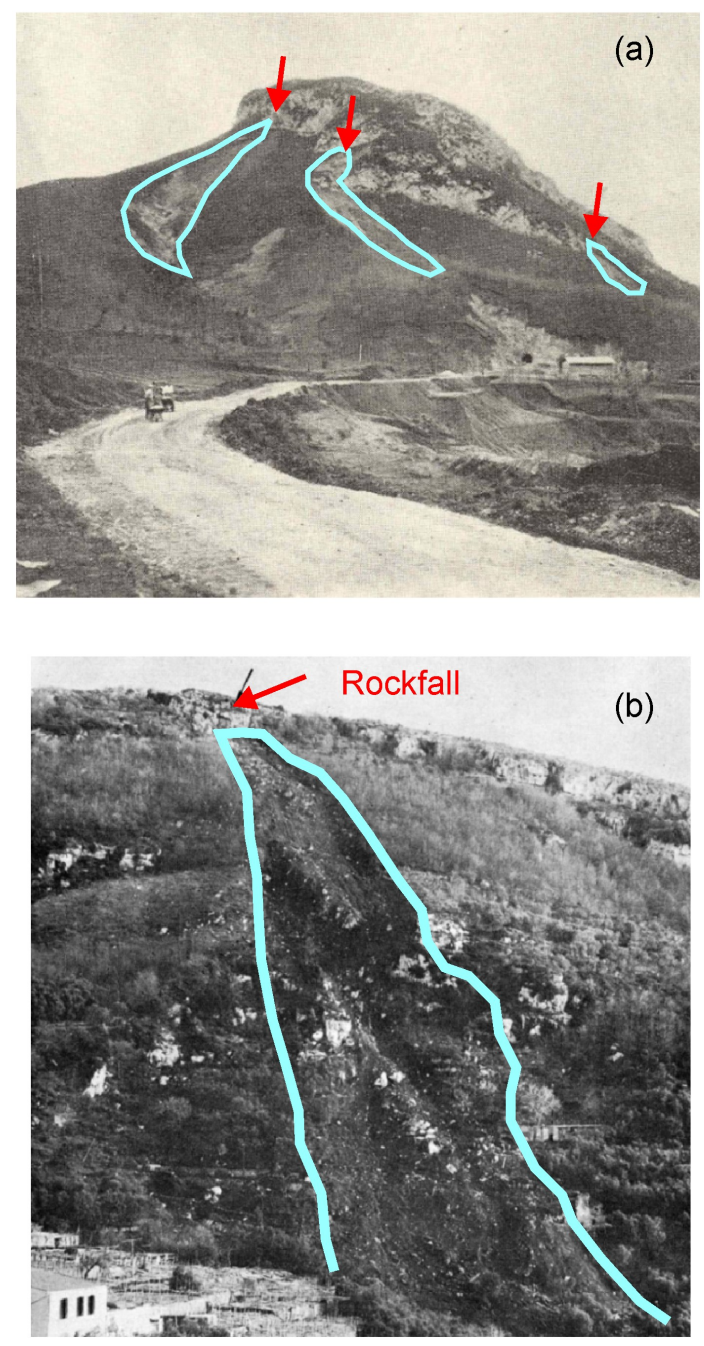

Fig. 2. Rockfall-induced debris flows affecting the Sorrento Peninsula-Lattari Mountains: (a) Mt. St. Liberatore in 1954; (b) Mt. St. Costanzo in 1973. The blue lines indicate the traces of rupture surfaces on original ground surfaces.

The entire area is crossed by eight drainage basins that currently cover areas varying from 0.5 to $3.0 \mathrm{~km}^{2}$. These drainage areas usually have small developed networks with ephemeral streams located in gullies and occasionally supplied by heavy rainfalls or by high-altitude ephemeral springs. Only two basins (Vallone Santa Croce and Petrara) show fairly hierarchized drainage networks with streams along linear faults striking N-S or NE-SW. The drainage networks do not flow into any main river in the floodplain and the occasional discharge flowing from them is collected in backwater tanks. The storage tanks have absorbing bottoms that facilitate water seepage. Sometimes the ephemeral streams are improperly used as mountain roads (known locally as alvei-strada) linking the plain with the wooded areas located at high altitude along the slope. Furthermore, these wooded areas are crossed by many tracks allowing the 


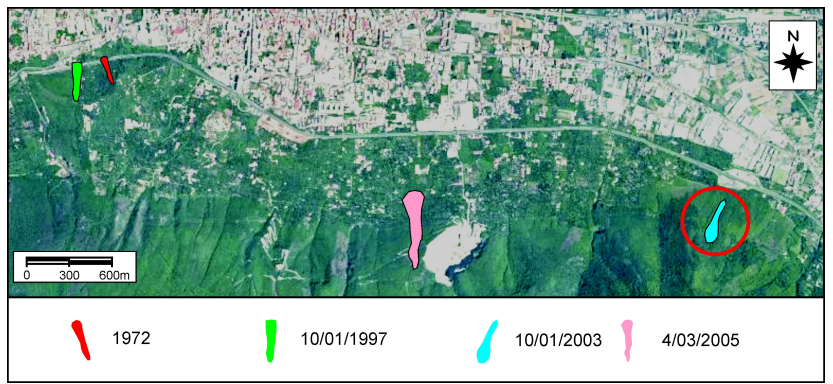

Fig. 3. Locations of debris-flow events affecting the slope of Mt. Sant'Angelo over the past 35 years. The red circle highlights the landslide considered in this paper.

transport of timber downhill. The altitude of the first slope break is about $150-200 \mathrm{~m}$ a.s.l. A more gentle stretch of mountainside follows downslope linking the carbonatic outcrop with the alluvial plane below. In this stretch of slope some ancient and recent detrital-alluvial fans are located at the outlet of lowly hierarchized drainage basins. Various cliffs generated by block faulting during the lower and middle Pleistocene stand out from the carbonate substratum. These faulting scarps are up to $30 \mathrm{~m}$ high.

The morphostructural framework of the Mt. St. Angelo slope has been conditioned by deposition of Holocene pyroclastic fall deposits. The presence of pyroclastic covers, especially in the steeper areas, makes wide sectors of the slope particularly susceptible to the triggering of debris slide/flows. These failures are commonly triggered when brief but heavy showers of rain occur, and particularly after prolonged rainfalls (Amanti et al., 1999; De Vita, 2000). Low mobilities affect the landslide debris with reach angle values varying between $25^{\circ}$ and $29^{\circ}$ (Budetta and De Riso, 2004). Welldocumented information is available regarding landslide activity over the past 35 years (Fig. 3). In 1972, a debris flow occurred along the slope near St. Pantaleone hill. The impact of a vehicle with the landslide deposit obstructing the southern lane of the Napoli-Salerno motorway caused the death of a driver (Guida et al., 1974). In 1997, a new debris flow occurred almost in the same place. The area affected by this landslide stretches downslope over $8000 \mathrm{~m}^{2}$; the landslide deposit involved $4500 \mathrm{~m}^{3}$ and, as in the 1972 event, it came to a halt on the motorway below. Three cars subsequently crashed into the debris and one of the drivers was killed (Budetta, 2002). In 2005, another landslide occurred in the Vallone Santa Croce basin. The detachment area was located about $370 \mathrm{~m}$ a.s.l. near a quarry track and the landslide deposit destroyed some buildings, as well as killing 3 inhabitants. In 2003 a landslide was triggered below a cliff in the Vallone Alfaterna basin and fortunately no one was killed. This event is discussed in detail below.

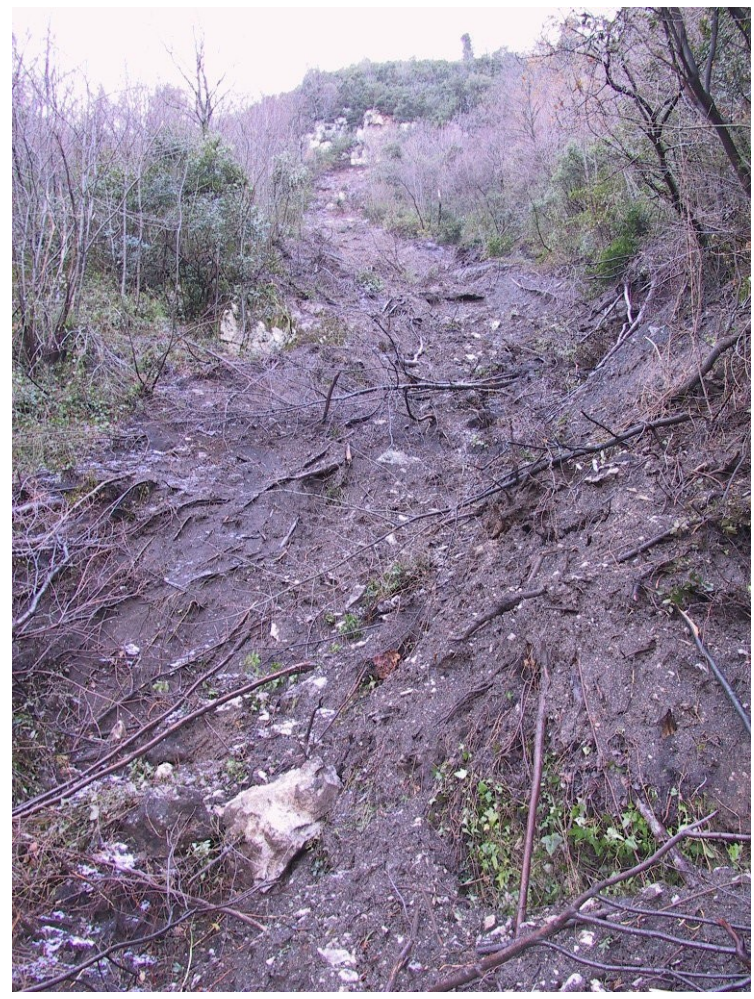

Fig. 4. View of the debris flow triggered by the rockfall on 10 January 2003.

\section{The case study}

On 10 January 2003 a rockfall of approximately $10 \mathrm{~m}^{3}$ af fected a cliff of some $25 \mathrm{~m}$ in height, placed in the most elevated sector of the Vallone Alfaterna basin, and triggered a debris flow along a slope below (Fig. 4). This drainage basin occupies an area of about $0.65 \mathrm{~km}^{2}$ situated above the Napoli-Salerno motorway. The basin shows no hierarchized drainage network: there is only one stream channel on a fault line striking $\mathrm{N}-\mathrm{S}$, flowing into a small detrital fan deposit, partly constituted by old pyroclastic-derived debris-flow materials. A depressed area almost elliptical in shape (a socalled zero-order basin or ZOB, cf. Guida, 2003) - is placed in the highest sector of the basin, where the pyroclastic cover shows a greater thickness in comparison with the surrounding areas (Fig. 5).

A geological survey (Fig. 5) supplemented by trenches on purpose excavated, made it possible to verify that the thickness of the pyroclastic cover overlaying the carbonatic bedrock varied from about $2.5 \mathrm{~m}$ at the top to about $8 \mathrm{~m}$ at the slope bottom. The stratigraphic survey in the debris-flow detachment area showed that the pyroclastic cover comprises: silty organic soil incorporating small pieces of pumice and several carbonatic fragments (thickness about $0.50 \mathrm{~m}$ ); silty-sandy $(0.70 \mathrm{~m})$; carbonate fragments and pumice in rich undifferentiated pyroclastic matrix $(1.0 \mathrm{~m})$; silty-sandy 

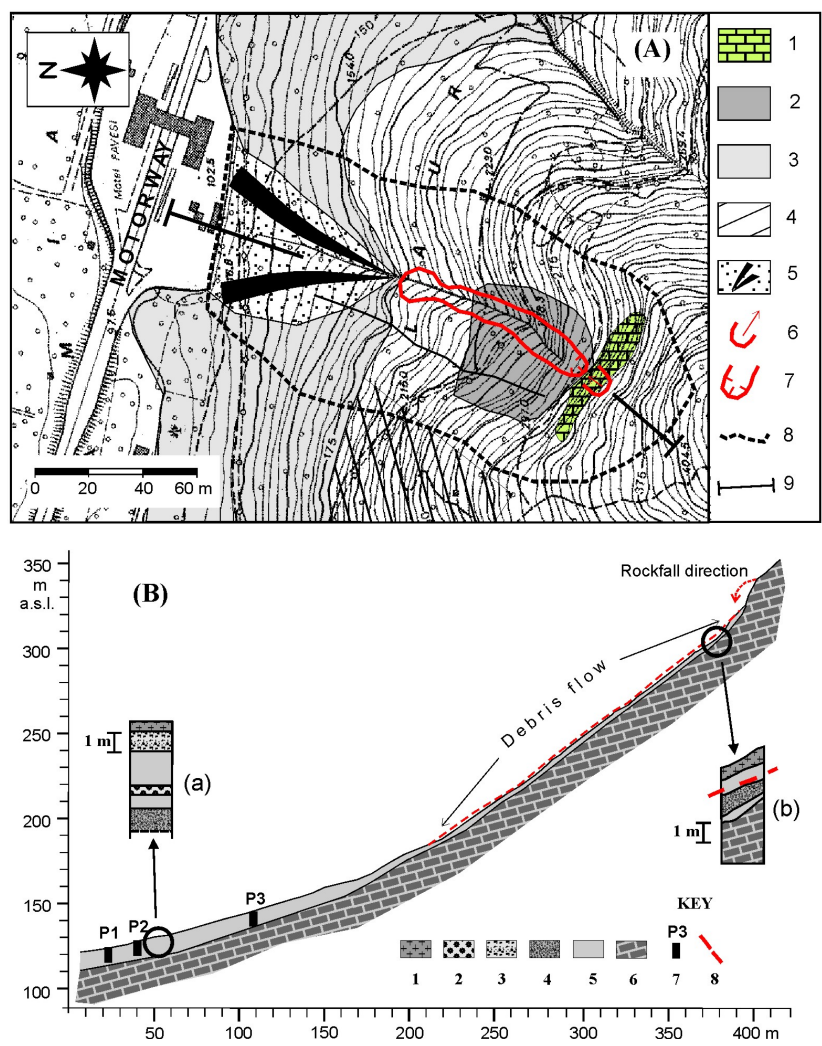

Fig. 5. (A) Geomorphological layout of the Vallone Alfaterna basin. (1) cliff; (2) zero-order basin - ZOB; (3) more gentle slope; (4) structural slope; (5) alluvial fan; (6) rockfall; (7) slide/debris flow; (8) watershed; (9) geological section trace. (B) Geological section. (a) stratigraphic column in the fan area; (b) stratigraphic column in the debris flow detachment area; (1) soil; (2) pumices in the pyroclastic matrix; (3) sandy pyroclastic deposits; (4) carbonatic fragments and pumices in the pyroclastic matrix; (5) silty-sandy volcanic ashes; (6) dolomitic-limestones; (7) trench; (8) sliding plane.

volcanic ash $(0.30 \mathrm{~m})$. Importantly, pumiceous layers are absent in the stratigraphic succession. Instead, in other sectors of the Mt. S. Angelo slope the pumice layers are very common, and date back to the $79 \mathrm{AD}$ eruption (Di Crescenzo and Santo, 2005). This occurrence helps account for a poor mobility of the 2003 landslide event. By contrast, owing to the presence of thick pumice layers with no cohesion and high water content, many landslides affecting the Sarno mountains and surrounding territories displayed high mobilities with reach angles varying between $8^{\circ}$ and $22^{\circ}$ (Calcaterra et al., 1999; Budetta and De Riso, 2004; Di Crescenzo and Santo, 2005).

As far as the debris-flow portion of the phenomenon is considered, the initial failure was characterized by a translational slide involving a very limited area of the most depressed area of an almost elliptical ZOB, where the pyroclastic cover was thicker. The sliding plane developed into the silty-sandy volcanic ashes, and the landslide mass of about

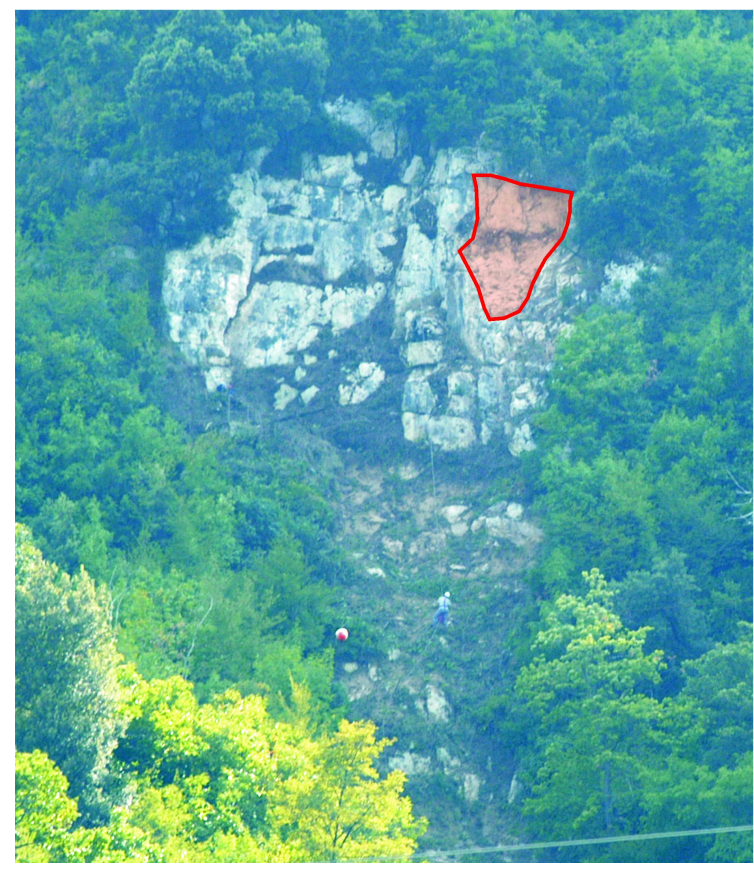

Fig. 6. Release area of the 10 January 2003 rockfall.

$500 \mathrm{~m}^{3}$ flowed into the small drainage basin, eventually stopping at the apex of the detrital fan deposit (Fig. 5).

The rockfall that triggered the debris flow involved stratified dolomitic-limestone outcropping on the cliff and occurred near the intersection between two wide tectonic joint sets affecting the rock mass; hence the rock failure can be classified as a wedge failure. The rockfall crown is located directly below the cliff edge; here the rock mass is overlain by a thin soil layer (Fig. 6). The joint orientation data (dip direction/dip), detected on the cliff by experienced rock-climber geologists, were plotted on equal area projections in order to define the main discontinuity sets affecting the rock mass (Fig. 7 and Table 1). The cyclographic projections of the sets, with respect to the cliff slope (015/87), highlight the possible occurrence of failures in the areas where rock masses with worse physical and mechanical properties outcrop, due to planar slides along the $\mathrm{S}$ set (bedding planes - 010/15) truncated from joints belonging to the K2 set (190/80), as well as wedge failures along joint intersections belonging to the $\mathrm{K} 1 / \mathrm{K} 3$ and $\mathrm{K} 1 / \mathrm{K} 4$ systems $(016 / 70$ and $050 / 75$, respectively). The spacing data grouped by the discontinuity set - were suitably divided into classes and processed statistically to determine the modal values (Table 1), ranging between moderately wide ( $\mathrm{S}$ and $\mathrm{K} 1$ sets) to very wide spacing (K3 and K4 sets). Except for the bedding planes displaying tight apertures $(<0.5 \mathrm{~mm})$, all the other tectonic joints have open and very open joints $(10 \div 100 \mathrm{~mm})$, almost all filled with pyroclastic and clayey materials from run-off. This condition reduces rock-mass permeability during heavy rainfalls. 


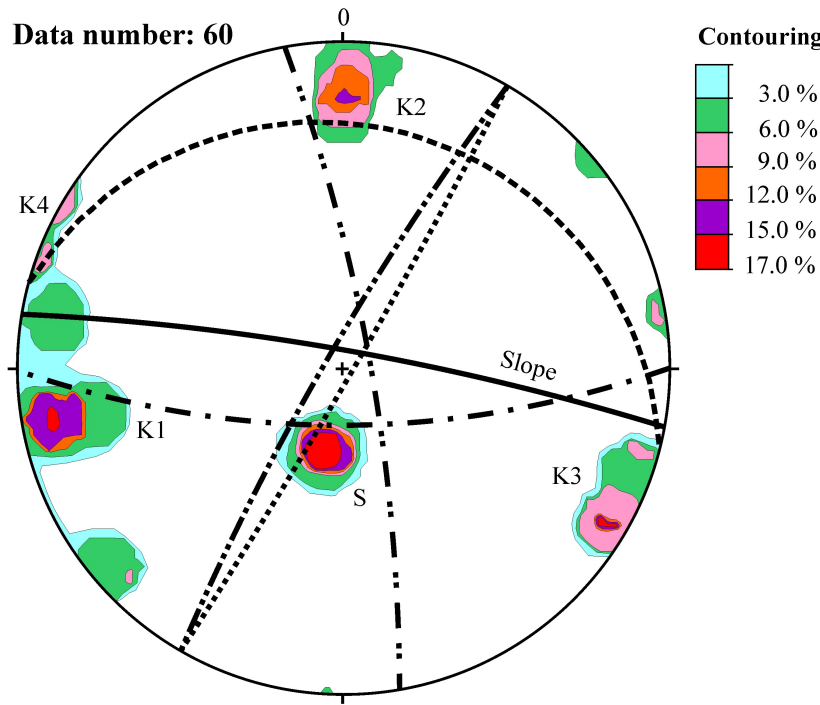

Fig. 7. Stereonet (Lambert-Schmidt equatorial net) of the joints affecting the cliff. S: bedding planes; K1-K4: joints.

On the basis of the modal spacing of the joint sets, and the related volumetric joint count $\left(J_{\mathrm{v}}=3.4 \mathrm{~J} / \mathrm{m}^{3}\right)$ detected for the entire rock mass along sampling lengths of $5.0 \mathrm{~m}$, the mean block volume $\left(V_{\mathrm{b}}\right)$ was calculated according to Palmstrom (2005), by:

$V_{\mathrm{b}}=\beta \cdot J_{\mathrm{v}}^{-3}$

where: $\beta$ is the block shape factor (36 for moderately flat blocks). $J_{\mathrm{v}}$ was defined as the sum of the number of joints per metre for each joint set, counted along $5 \mathrm{~m}$ perpendicular sampling lengths. This value agrees with the detected joint spacing data and, according to Palmstrom (2005), define a moderate degree of jointing for the analysed rock mass.

The calculated $V_{\mathrm{b}}$ value $\left(0.92 \mathrm{~m}^{3}\right)$ agrees with the evidence regarding the mean volume $\left(0.96 \mathrm{~m}^{3}\right)$ of the more frequently unstable blocks still outcropping on the cliff, and connected to the rock mass by means of intact rock bridges (Fig. 8). During the rockfall, block mobilisation occurred through the sudden breakage of these intact rock parts, allowing the movement of boulders that were previously connected to the stable rock mass.

In consequence of the rockfall, numerous impacts on the rocky outcrops emerging from the cliff caused fragmentation and wide lateral propagation of boulders. In-situ evidence showed that along the gentler slope below, the boulders were scattered in accordance with an apical angle of about $40^{\circ}$. Due to the numerous rebounds along the trajectory itself, the most advanced boulder (approximately $0.9 \mathrm{~m}^{3}$ ) travelled about $20 \mathrm{~m}$ below the cliff toe. However, one cannot discount that the boulder was carried downslope by the debris flow triggered by the rockfall. In neighbouring areas to the debris flow in question, some elongated impact marks impressed on the grass-covered ground surface were detected. Further-
Table 1. Main joint sets affecting the rock mass outcropping on the cliff. S: bedding planes; K1-K4: structural joints.

\begin{tabular}{llrr}
\hline $\begin{array}{l}\text { Joint } \\
\text { set }\end{array}$ & $\begin{array}{l}\text { Dip } \\
\text { direction }\left({ }^{\circ}\right)\end{array}$ & $\begin{array}{r}\text { Dip } \\
\left({ }^{\circ}\right)\end{array}$ & $\begin{array}{r}\text { Spacing } \\
(\mathrm{cm})\end{array}$ \\
\hline $\mathrm{S}$ & 010 & 15 & 50 \\
$\mathrm{~K} 1$ & 080 & 80 & 60 \\
$\mathrm{~K} 2$ & 190 & 80 & 100 \\
$\mathrm{~K} 3$ & 285 & 85 & 250 \\
$\mathrm{~K} 4$ & 110 & 85 & 270 \\
\hline
\end{tabular}
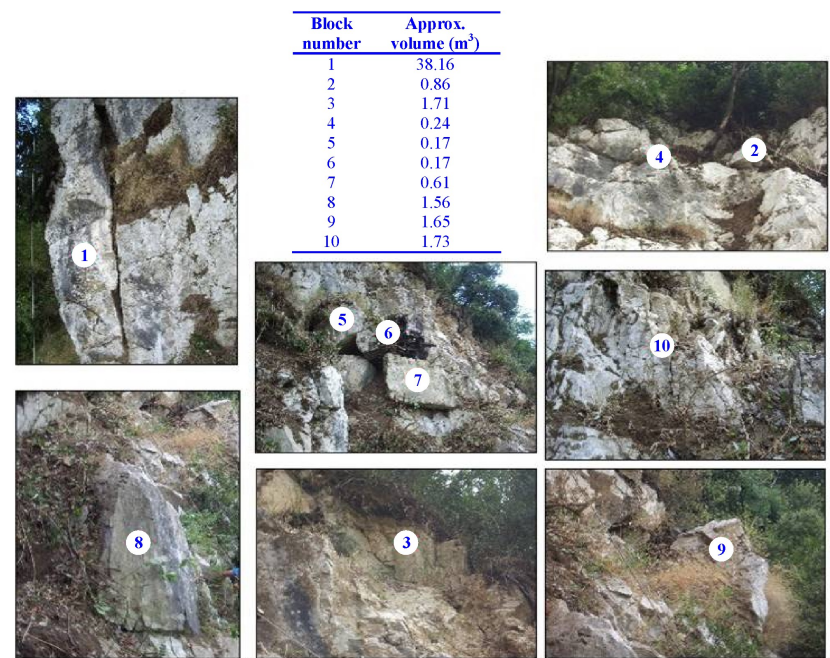

Fig. 8. Potentially unstable blocks, and related volumes, outcropping on the cliff.

more, some boulders appear to have pierced the ground to depths varying between 5 and $12 \mathrm{~cm}$, the minimum values situated near the upslope part of the block base. This occurrence and the elongated shape of the marks prove that, after landing, the boulders pierced the soil, and slid downslope for some tens of centimetres. Most probably, sliding phenomena were due to the local high gradient of the slope, and low angle of thrust at impact between the trajectory boulder and the slope. The shape and location of impact marks prove the existence and importance of the block face-slope interaction in the sliding motion mechanism. These occurrences are very important for reconstructing block trajectories and their propagation modes (Paronuzzi, 2009).

As the rockfall was triggered by abundant rainfall, a meteorological study was performed. There were few recording rain gauges in the surrounding area with altitudes comparable with the landslide area. The Sarno Sanatorio rain gauge, about $7 \mathrm{~km}$ from Mt. St. Angelo slope, can be considered the most representative because of its altitude. Antecedent rainfall recorded at Sarno Sanatorio from 19:00 LT on 6 January to $05: 00 \mathrm{LT}$ on 10 January 2003 amounts to $111.2 \mathrm{~mm}$ 


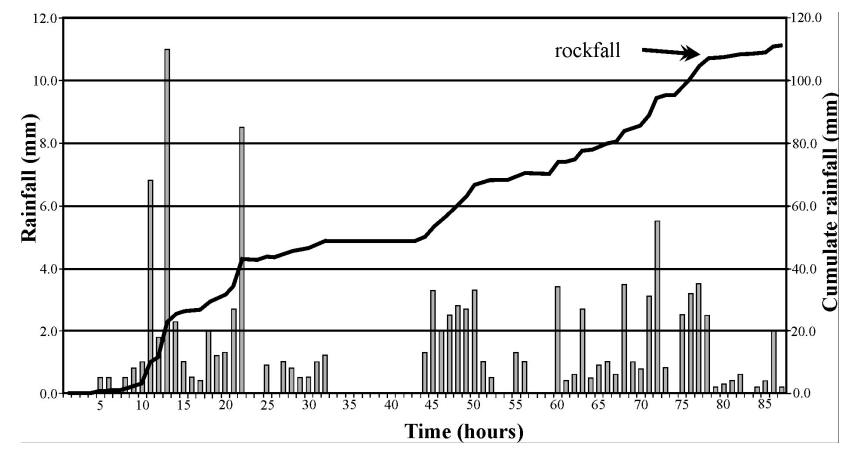

Fig. 9. Antecedent and cumulative rainfalls recorded at the Sarno Sanatorio rain gauge from 19:00 LT on 6 January to 05:00 LT on 10 January 2003.

(Regione Campania, 2009). Similar values were recorded at other rain gauges in the area (Baronissi and Cava dei Tirreni). The 6 to 10 January event showed a first burst from 19:00 LT on $6 / 01$ to $22: 00 \mathrm{LT}$ on $7 / 01$, with a maximum rainfall intensity of $11 \mathrm{~mm} / \mathrm{h}$; the mean intensity over $28 \mathrm{~h}$ was $1.74 \mathrm{~mm} / \mathrm{h}$ (Fig. 9). After a break of $11 \mathrm{~h}$, the rain persisted nearly continuously from 10:00 LT on 8/01 to $05: 00 \mathrm{LT}$ on $10 / 01$ with a maximum rainfall intensity of $5.5 \mathrm{~mm} / \mathrm{h}$; the mean intensity over $44 \mathrm{~h}$ was $1.42 \mathrm{~mm} / \mathrm{h}$. The rainfall pattern suggests the occurrence of a not intense but prolonged event, able to fill the main joints of the carbonatic rock mass and thus trigger the rockfall. It should also be highlighted that the 6 to 10 January meteorological event occurred after a very rainy autumnal season.

\section{Methodology}

In order to ascertain the role played by kinetic energies of falling blocks in causing the debris flow, rock fall numerical modelling was performed. Using field data regarding impact marks and the predominant mode of motion, it was possible to reconstruct the rock-fall trajectories and to estimate more suitable normal and tangential impact energy restitution $\left(r_{\mathrm{n}}\right.$ and $\left.r_{\mathrm{t}}\right)$ and rolling friction $\left(\tan \phi_{\mathrm{r}}\right)$ coefficients. This was carried out by means of a back-analysis that uses a 2-D code (ROCFALL 4.0 by Rocscience, 2002), designed to compute distributions of energy, velocity and bounce-height along slope profiles. Because this program uses a lumped-mass method, the boulders are reduced to a single point for the purposes of the analysis, and possible boulder fragmentation during propagation is not considered. According to this code the block trajectory depends on the $r_{\mathrm{n}}$ and $r_{\mathrm{t}}$ as well as $\tan \phi_{\mathrm{r}}$ coefficients, whereas it is independent of the block mass. The friction angle $(\phi)$, as it is used in ROCFALL, is the critical angle of slope segments for the blocks moving downslope: if the slope segment is inclined more than this angle, the rocks are allowed to move downslope; if it is inclined less than this, the blocks come to rest on the segment. Slope roughness, as defined in ROCFALL, is the standard deviation $(\sigma)$ of the slope segment angles. The $\sigma$ values for both energy restitution coefficients and slope roughness allow high variability of these parameters to be taken into account, particularly for the local surface angle of slope segments. Each time a rock impacts a slope segment with a non-zero slope roughness, the actual slope angle results from sampling the normal distribution for that slope segment. The stochastic nature of the rock fall process and the variability of the relevant parameters (slope geometry, energy restitution and rolling friction coefficients, velocities and slope roughness) were introduced through a Monte Carlo sampling technique. The above-mentioned 2$\mathrm{D}$ approach was performed because it allows analysis of the mean behaviour of the blocks bouncing on a natural slope, especially as regards the block translation velocity and the air trajectories (Paronuzzi, 2009).

In order to evaluate the impact force of a boulder landing on the slope, an attempt was performed using the suggested approach by Calvetti et al. (2005) and Calvetti and Di Prisco (2007). Using an experimental device and numerical simulations by means of a distinct element code, the authors derived practice correlations between impact energy, impact force and stress on artificial strata covering shelters, for falling spheres with variable radius. With reference to peak impact force $\left(F_{\mathrm{MAX}}\right)$, the results of experiments and numerical simulations allowed the following overall correlation to be established:

$F_{\text {MAX }}=F_{0} \cdot\left(E / E_{0}\right)^{n}$

where $E$ is the kinetic energy of the boulder, $E_{0}$ is the reference kinetic energy of the sphere (in the experimental tests $\left.E_{0}=98.1 \mathrm{~kJ}\right)$, and $F_{0}$ and $n$ are experimental coefficients. $F_{0}$ depends on the mechanical properties of the dissipative granular material such as the stiffness modulus, but is irrespective of the thickness of the layer itself. Coefficients $F_{0}$ and $n$ can be evaluated as functions of the block radius $(r)$, whereas the a-dimensional ratio $\left(E / E_{0}\right)$ is plotted as a function of $F_{\mathrm{MAX}}$ and $r$. The above correlation was derived by impact tests on the horizontal surface. In the case of impact trajectories on inclined surfaces, Calvetti and Di Prisco (2007), suggest reducing the calculated value by about $10-20 \%$.

At the impact point, the block's impact energy is absorbed and maximum penetration is reached when this energy is fully dissipated. On the basis of small-scale laboratory experiments, Heidenreich and Labiouse (2004) showed that the soil compaction degree has a significant influence on the penetration phenomenon. What is more difficult is determining the penetration depth for boulders with inclined trajectories dropping on slopes with variable inclination. Depending on a number of variables such as block energy and shape, angle between slope and trajectory, and soil conditions, under certain circumstances a landed block may start sliding down a slope. Wang and Cavers (2008) presented a simple procedure for calculating the maximum penetration depth for a sliding 
Table 2. Main geo-mechanical parameters and related standard deviations $(\sigma)$ adopted in the rockfall simulations.

\begin{tabular}{lllllll}
\hline Material & $\begin{array}{l}\text { Mean } \\
\text { normal } \\
\text { coefficient } \\
\text { of restitution } \\
\left(r_{\mathrm{n}}\right)\end{array}$ & $\begin{array}{l}\text { Mean } \\
\text { tangential } \\
\text { coefficient } \\
\text { of restitution } \\
\left(r_{\mathrm{t}}\right)\end{array}$ & $\begin{array}{l}\text { Std } \\
\text { dev }\end{array}$ & $\begin{array}{l}\text { Mean } \\
\text { friction } \\
\text { angle }\left({ }^{\circ}\right)\end{array}$ & $\begin{array}{l}\text { Std } \\
\text { dev } \\
\left({ }^{\circ}\right)\end{array}$ & $\begin{array}{l}\text { Slope } \\
\text { roughness: } \\
\text { std dev }\left({ }^{\circ}\right)\end{array}$ \\
\hline Fractured dolomitic limestones & 0.48 & 0.73 & 0.04 & 25 & 2 & 3 \\
\hline $\begin{array}{l}\text { Pyroclastic talus with detrital } \\
\text { fragments and some vegetation }\end{array}$ & 0.25 & 0.55 & 0.04 & 25 & 2 & 2 \\
\hline
\end{tabular}

block $\left(H_{\mathrm{o}}\right)$. The suggested relationship correlates penetration depth to the mass of the block, the slope inclination, and geotechnical parameters such as: the soil bearing capacity factor $(N \gamma)$, the soil friction angle $(\phi)$, and the friction angle between the block and slope surface $\left(\phi_{\mathrm{s}}\right)$. The penetration depth $\left(H_{\mathrm{o}}\right)$ of a sliding block can be calculated by:

$H_{\mathrm{o}}=1.874\left[\left(1-\tan \phi_{s} / \tan \theta\right)\left(W \sin ^{2} \theta / \gamma N \gamma\right) h\right]^{1 / 3}$

where $\phi_{\mathrm{s}}$ is the sliding friction angle between block and slope surface, $\theta$ is the slope angle, $W$ is the block weight, $\gamma$ is the soil unit weight, $N \gamma$ is Terzaghi's bearing capacity factor, related to the contribution from the self-weight of the soil, and $h$ is the sliding height, related to the block travelling distance (L) along the slope.

\section{Results}

Using the above approaches, in the triggering area of the debris flow, kinetic energy, impact force on the detritalpyroclastic slope, and the consequent maximum penetration depth were calculated for a landing and sliding block. Since these values concern a single rock volume of about $1.0 \mathrm{~m}^{3}$, they undoubtedly provide a lower estimate of the total stress applied by the entire rockfall (about $10 \mathrm{~m}^{3}$ ). The block volume used in rock-fall simulations was selected according to calculated $V_{\mathrm{b}}\left(0.92 \mathrm{~m}^{3}\right)$ and in-situ evidence of the more frequently unstable blocks outcropping on the cliff (Fig. 8).

In order to ascertain the role played by kinetic energies of falling blocks in causing the debris flow, seven topographical cross sections of the entire slope, between boulder detachment points and endpoints on the pyroclastic cover, were reconstructed. In-situ evidence regarding the rockfall starting points, boulder volumes, endpoints and impact marks was used to perform trajectory back-analyses with the ROCFALL code. Having set the initial horizontal and vertical velocities to zero at starting point, the normal $\left(r_{\mathrm{n}}\right)$ and tangential $\left(r_{t}\right)$ coefficients of restitution for both dolomitic-limestones and the pyroclastic cover were investigated (Table 2) by a "trial-and-error" method (Richards, 1988). For the rolling friction angle $\left(\phi_{\mathrm{r}}\right)$ along pyroclastic talus segments, a uniform value of $25^{\circ}$ was adopted. This value was derived from rock-fall back-analyses, based on the surveyed impact marks. Furthermore, simulations show that rebound trajectories require higher values of the two coefficients of restitution for dolomitic-limestone than for pyroclastic soil ( 0.48 vs. 0.25 and 0.73 vs. 0.55 , respectively) to reproduce the rebound sequence observed in the study area. These values are generally consistent with those suggested in the scientific literature (Richards, 1988; Chau et al., 2002; Giani et al., 2004), demonstrating that boulders bounced on the soil slope with greater energy loss than on the dolomitic-limestone cliff.

After reconstructing the trajectories of 7000 blocks along the above profiles of the entire slope up to the endpoints, a suitable pattern of kinetic iso-energy curves was created (Fig. 10), interpolating energy values detected along the $\mathrm{x}$ coordinates of each profile. The kinetic energy curve measures the highest kinetic energy (translational+rotational) that the boulder attained while passing each horizontal location, particularly at the debris flow starting point (about $319 \mathrm{~m}$ a.s.1.). The iso-energy map shows a concise rockfall hazard scenario of the entire slope. In the map, total kinetic energy levels larger than $200 \mathrm{~kJ}$ are typical of the cliff and its base. These values are due to predominant free-fall motions of boulders. The absolute maximum energy (about $300 \mathrm{~kJ}$ ) marks a small area located in the middle sector of the cliff, near the eastern edge. Along the slope below, energies rapidly decrease from about $60-180 \mathrm{~kJ}$ in the triggering area of the slide, owing to prevalent rolling and sliding movements of boulders, to about $5-20 \mathrm{~kJ}$ along the gentler slope below, coinciding with the upper sector of the channelled debris flow. This energy drop is caused by the presence of pyroclastic soil with lower normal and tangential coefficients of restitution as well as the local slope gradient, favouring sliding movements until the endpoints are reached.

In order to evaluate the impact force of a boulder of about $1 \mathrm{~m}^{3}$ colliding against the source area of the debris flow, the above relationship suggested by Calvetti and Di Prisco (2007) was applied. The details of trajectories of landing and sliding blocks along a topographical profile passing through the landslide crown area are presented in Fig. 11. Usually, the angle of impact $(\alpha)$ with the slope is about $23^{\circ}$ and the boulders move with velocity $\left(V_{i}\right)$ of about $14 \mathrm{~m} / \mathrm{s}$ (also this 


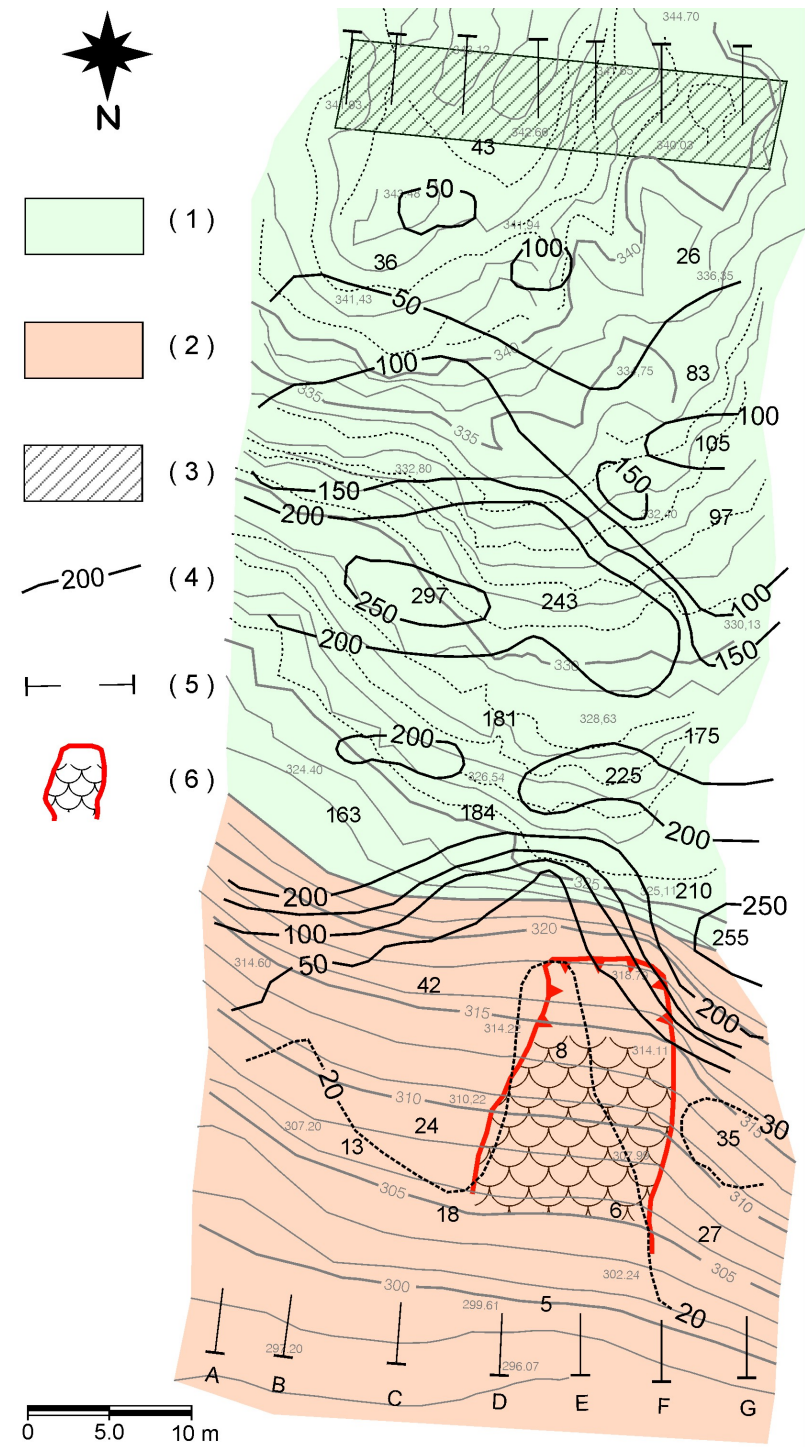

Fig. 10. Iso-energy (total kinetic energies) map of the study area. (1) dolomitic-limestones; (2) pyroclastic deposits; (3) instability zone, containing the rockfall starting points; (4) iso-energy curve and related value in $\mathrm{kJ}$; (5) slope profile used for performing trajectory back-analysis with the ROCFALL code; (6) debris-flow landslide crown.

mean value was derived from ROCFALL simulations). Let $120 \mathrm{~kJ}$ be the mean total kinetic energy $E ; F_{0}$ and $n$ being the coefficients evaluated as functions of the block radius $r$, the $F_{\text {MAX }}$ of an impacting boulder on the slope angle $\left(\theta=45^{\circ}\right)$ is estimated at about $800 \mathrm{kN}$. The value of the reference kinetic energy $\left(E_{0}=98.1 \mathrm{~kJ}\right)$ was taken from the experimental tests performed by Calvetti and Di Prisco (2007). As ROCFALL uses the lumped-mass method, the $F_{\text {MAX }}$ value was calculated with reference to a hypothetical spherical block of about $1 \mathrm{~m}^{3}$ (block radius about $62 \mathrm{~cm}$ ). At impact point, the tangential and normal force are $F_{\mathrm{S}}=800 \times \cos 23^{\circ}=736.4$ $\mathrm{kN}$, and $F_{\mathrm{n}}=800 \times \sin 23^{\circ}=312.6 \mathrm{kN}$, respectively. Given

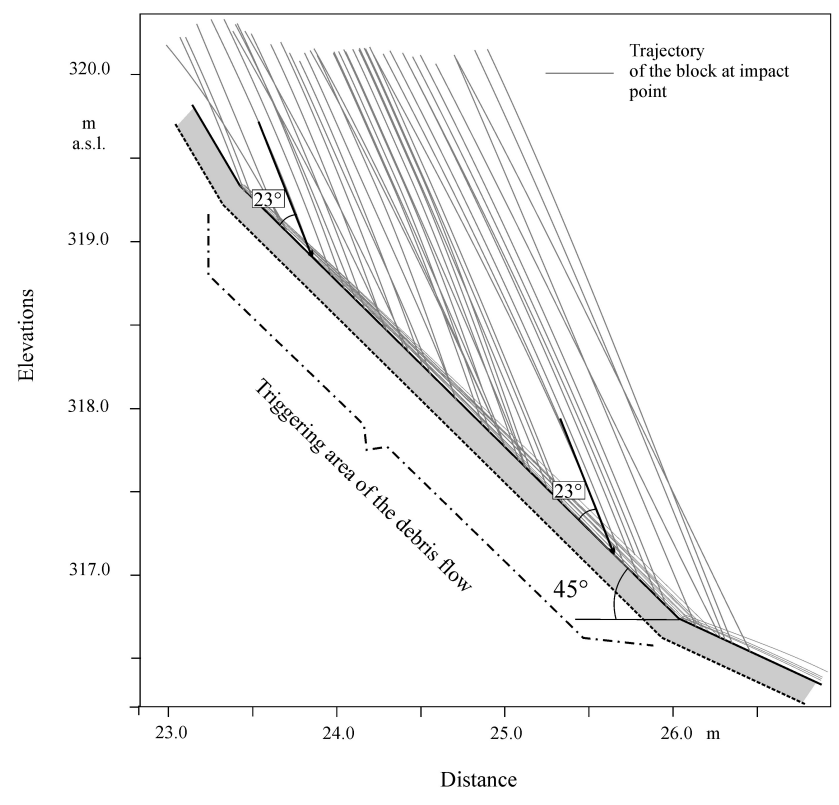

Fig. 11. Details of trajectories of landing and sliding simulated blocks, along a topographical profile passing through the landslide crown area.

that the entire rockfall is about $10 \mathrm{~m}^{3}$, and in-situ evidence shows some crushed blocks (with volumes varying between 0.5 and $0.9 \mathrm{~m}^{3}$ ) widely scattered along the slope, it is very probable that on repeated occasions it was hit by boulders. During the rockfall event, large tangential (shear) forces were imposed on the slope by several impacts of boulders with high kinetic energies landing with a low angle of impact. After landing, owing to the local gradient of the slope and their elongated shape, the boulders slid down the slope. Consequently, much kinetic energy was dissipated during the sliding phenomenon. Using the suggested procedure by Wang and Cavers (2008), and the displayed data in Table 3, the maximum depth of penetration into the ground of a sliding block $\mathrm{H}_{\mathrm{o}}$ was estimated at about $16 \mathrm{~cm}$. This value gives an indicative value of the block's considerable impact energy since the maximum penetration is reached when this energy is fully dissipated. Due to the high impact force of the boulder colliding at a low angle of impact against the slope, it tends to penetrate more deeply into the slope, transferring its energy to the surrounding soil. Nevertheless, the above $\mathrm{H}_{\mathrm{o}}$ value should be treated with caution because there is scant in-situ evidence to confirm the proposition.

\section{Discussion and conclusions}

Several simplifications and approximations concerning boulder kinetic energy, impact force and the maximum depth of penetration were introduced in the calculations. As the employed rockfall simulation code uses the lumped-mass method, the boulders are reduced to single points, and during 
Table 3. Geotechnical, geometrical and topographical data used to calculate the maximum penetration depth of the block.

\begin{tabular}{lll}
\hline Soil geotechnical properties & Rock block & Slope conditions \\
\hline Unit weight $(\gamma) 18 \mathrm{kN} / \mathrm{m}^{3}$ & Unit weight $(\gamma) 26 \mathrm{kN} / \mathrm{m}^{3}$ & Slope angle $(\theta) 45^{\circ}$ \\
Friction angle $(\phi) 38^{\circ}$ & Face area $(a) 1 \mathrm{~m}^{2}$ & $\begin{array}{l}\text { Friction angle between block } \\
\text { and slope surface }\left(\phi_{\mathrm{s}}\right) 25^{\circ}\end{array}$ \\
$\begin{array}{l}\text { Terzaghi's bearing capacity } \\
\text { factor }(N \gamma) 67.32\end{array}$ & Block weight $(W) 26 \mathrm{kN} / \mathrm{m}$ & \\
& $\begin{array}{l}\text { Block travelling distance }(L) 0.5 \mathrm{~m} \\
\text { Block travelling mode: sliding }\end{array}$ & \\
\hline
\end{tabular}

the fall, fragmentation phenomena are not considered. In order to take into account the three-dimensional effects of trajectories, 3-D codes would appear more suitable though available data do not allow their selection. In calculating the equivalent impact force on the soil slope, the block shape was disregarded and the $F_{\mathrm{MAX}}$ value evaluated with reference to a hypothetical spherical block of about $1 \mathrm{~m}^{3}$, according to the approach suggested by Calvetti and Di Prisco (2007). Finally, also the estimate of the maximum sliding penetration depth is not supported by much in-situ evidence.

In spite of such constraints, there is evidence regarding the high kinetic energies affecting the rockfall, such as: block masses, falling heights, and high soil slope gradient. During the rockfall, several falling and rebounding blocks must have severely hit the slope below. Due to the low angle of trajectories at the main impact point, a high tangential force was quickly transferred to the saturated detrital-pyroclastic soil. It is worth noting that during experimental tests, at impact on compacted sand strata, spherical blocks abruptly decelerate in an elapsed time of about one hundredth of second (Calvetti and Di Prisco, 2007). Because of such rapid dynamic loading, the saturated slope failed under undrained conditions. With reference to dynamic-loading ring-shear tests on saturated volcanoclastic deposits, Sassa et al. (2004) demonstrated that only a slight additional shear stress was required to cause failure under undrained conditions. Owing to the difficulty in quantifying all the variable requirements in this case-history, soil stability back-analyses should lead to a better prediction of the required dynamic load for slope failure.

The study showed that a translational slide was triggered by the impact of boulders creating excess pore pressure on the slope. This occurrence is mainly related to the local rockfall mechanism involved in the complex landslide analysed in the study. However, as demonstrated by some previous events (Mt. St. Liberatore in 1954, Mt. St. Costanzo in 1973, Palma Campania in 1986, Sarno and Siano in 1998), such landslides are not rare in the northwestern sector of Campania when the soil slopes below the cliffs achieve almostcomplete saturation. Consequently, it is important to seek to establish a impact force threshold value, for debris flow triggering. In the analysed case study, it seems that instability occurs as a result of moderate loads being applied. For numerical modelling a preliminary rockfall analysis is necessary, even though it is difficult to evaluate the required kinematic parameters correctly. Local variable geomorphological, hydrogeological and geotechnical conditions assume a very important role and for such a purpose, sufficient data are not yet available.

Acknowledgements. The author is grateful to P. T. Bobrowsky, G. R. Iovine and O. Katz for their valuable comments and suggestions that improved this paper. This work was carried out with financial contributions from the Federico II University of Naples under P. Budetta.

Edited by: O. Katz

Reviewed by: G. G. R. Iovine and P. T. Bobrowsky

\section{References}

Amanti, M., Ducci, D., Onorati, G., and Ventura, R.: Relazione tra gli eventi franosi del maggio 1998 e la piovosità dell'area di Sarno, Proc. Conf. "Rischio idrogeologico e difesa del suolo", Accademia Nazionale dei Lincei, 154, 385-392, 1999 (in Italian).

Brancaccio, L., Cinque, A., Russo, F., and Sgambati, D.: Osservazioni geomorfologiche sulle frane del 5-6 maggio 1998 del Pizzo d'Alvano (Monti di Sarno, Campania), in: "Studi geografici e geologici in onore di Severino Belloni", edited by: Orombelli, G., Genova, 81-123, 1999 (in Italian).

Budetta, P.: Risk assessment from debris flows in pyroclastic deposits along a motorway, Italy, Bull. Eng. Geol. Environ., 61, 293-301, 2002.

Budetta, P. and De Riso, R.: The mobility of some debris flows in pyroclastic deposits of the northwestern Campanian region (southern Italy), Bull. Eng. Geol. Environ., 63, 293-302, 2004.

Cairo, R. and Dente, G.: A flowslide in a pyroclastic soil fill, in: Proc. Int. Conf. on Fast Slope Movements-Prediction and Prevention for Risk Mitigation, edited by: Picarelli, L., Patron, Napoli, 1, 53-61, 2003.

Calcaterra, D., Parise, M., Palma, B., and Pelella, L.: The May 5th 1998 landsliding event in Campania, Southern Italy: inventory of slope movements in the Quindici area, in: Proc. Int. Symp. 
on slope stability engineering, Balkema, Rotterdam, 1361-1366, 1999.

Calcaterra, D., De Riso, R., and Santo, A.: Landslide hazard and risk mapping: experiences from Campania, Italy, in: Proc. Int. Conf. on Fast Slope Movements-Prediction and Prevention for Risk Mitigation, edited by: Picarelli, L., Patron, Napoli, 1, 6370, 2003.

Calvetti, F., Di Prisco, C., and Vecchiotti, M.: Experimental and numerical study of rock-fall impacts on granular soils, Italian Geotechnical Journal-RIG, 59(4), 95-109, 2005.

Calvetti, F. and Di Prisco, C.: Linee guida per la progettazione di gallerie paramassi, Starrylink Ed., Brescia, 184 pp., 2007 (in Italian).

Cascini, L., Cuomo, S., and Sorbino, G.: Flow-like mass movements in pyroclastic soils: remarks on the modelling of triggering mechanisms, Italian Geotechnical Journal-RIG, 59(4), 11$31,2005$.

Chau, K. T., Wong, R. H. C., and Wu, J. J.: Coefficient of restitution and rotational motions of rockfall impacts, Int. J. Rock Mech. Min. Sci., 39, 69-77, 2002.

Civita, M., De Riso, R., Lucini, P., and Nota d'Elogio, E.: Studio delle condizioni di stabilità dei terreni della Penisola sorrentina, Geologia Applicata ed Idrogeologia, 10, 129-188, 1975 (in Italian).

Costa, J. E. and Williams, G. D.: Debris flows dynamics, US Geological Survey, Open file report 84/606 (Video), Reston, VA, 1984.

Crosta, G.: An example of unusual complex landslide: from a rockfall to a dry granular flow?, Geologica Romana, 30, 175-184, 1994.

Crosta, G. B. and Dal Negro, P.: Observations and modelling of soil slip-debris flow initiation processes in pyroclastic deposits: the Sarno 1998 event, Nat. Hazards Earth Syst. Sci., 3, 53-69, doi:10.5194/nhess-3-53-2003, 2003.

Del Prete, M., Guadagno, F. M., and Hawkins, A. B.: Preliminary report on the landslide of 5 May 1998, Bull. Eng. Geol. Environ., 57, 113-129, 1998.

De Riso, R., Budetta, P., Calcaterra, D., and Santo, A.: Le colate rapide in terreni piroclastici del territorio campano, Proc. Conf. "Previsione e prevenzione di movimenti franosi rapidi", GEAM Associazione Georisorse e Ambiente, 133-150, 1999 (in Italian).

De Riso, R., Budetta, P., Calcaterra, D., and Santo, A.: Riflessioni sul comportamento delle colate rapide non incanalate della Campania, alla luce delle conoscenze pregresse, Proc. Conf. "La mitigazione del rischio da colate di fango a Sarno e negli altri Comuni colpiti dagli eventi del maggio 1998", Commissariato per l'emergenza idrogeologica in Campania, 81-92, 2005 (in Italian).

De Vita, P.: Fenomeni di instabilità delle coperture piroclastiche dei Monti Lattari, di Sarno e di Salerno (Campania) ed analisi degli eventi pluviometrici determinanti, Quaderni di Geologia Applicata, 7(2), 213-239, 2000 (in Italian).

Di Crescenzo, G. and Santo, A.: Analisi geomorfologica delle frane da scorrimento-colata rapida in depositi piroclastici della Penisola sorrentina, Geografia Fisica e Dinamica Quaternaria, 22, 57-72, 1999 (in Italian).

Di Crescenzo, G. and Santo, A.: Debris slides-rapid earth flows in the carbonate massifs of the Campania region (Southern Italy): morphological and morphometric data for evaluating triggering susceptibility, Geomorphology, 66, 255-276, 2005.

Esposito, F. and Guadagno, F. M.: Some special geotechnical properties of pumice deposits, Bull. Eng. Geol. Environ., 57, 41-50, 1998.

Fiorillo, F., Guadagno, F. M., Aquino S., and De Blasio, A.: The December 1999 Cervinara landslides: further debris flows in the pyroclastic deposits of Campania (southern Italy), Bull. Eng. Geol. Environ., 60, 171-184, 2001.

Geertsema, M., Clague, J. J., Schwab, J. W., and Evans, S. G.: An overview of recent large catastrophic landslides in northern British Columbia, Canada, Engineering Geology, 83, 120-143, 2006.

Giani, G. P., Giacomini, A., Migliazza, M., and Segalini, A.: Experimental and theoretical studies to improve rock fall analysis and protection work design, Rock Mech. Rock Eng., 37(5), 369-389, 2004.

Guadagno, F. M., Palmieri, M., Siviero, V., and Vallario, A.: La frana di Palma Campania del 22 Febbraio 1986, Geologia Tecnica, 4, 18-29, 1986 (in Italian).

Guadagno, F. M. and Magaldi, S.: Considerazioni sulle caratteristiche geotecniche dei suoli allofanici di copertura delle dorsali carbonatiche campane, Quaderni di Geologia Applicata, 7(1), 143-160, 2000 (in Italian).

Guadagno, F. M. and Perriello Zampelli, S.: Triggering mechanisms of the landslides that invested Sarno, Quindici, Siano and Bracigliano (Southern Italy) on May 5-6, 1998, in: Proc. 8th Int. Symp. on Landslides, edited by: Bromhead, E. M., Dixon, J., and Ibsen, M. L., Tomas Telford, London, 2, 671-676, 2000.

Guadagno, F. M., Forte, R., Revellino, P., Fiorillo, F., and Focareta, M.: Geomorphology of the source areas of the flows involving the pyroclastic soils of Campania (southern Italy), Geomorphology, 66, 237-254, 2005.

Guida, M., Iaccarino, G., and Vallario, A.: Alcune considerazioni sui fenomeni di dissesto e sulla difesa del suolo nella Penisola sorrentina, Geologia Tecnica, 2, 15-35, 1974 (in Italian).

Guida, D.: The role of Zero-Order Basins in flowslides-debris flows occurrence and recurrence in Campania (Italy), in: Proc. Int. Conf. on Fast Slope Movements-Prediction and Prevention for Risk Mitigation, edited by: Picarelli, L., Patron, Napoli, 2, 255262, 2003.

Heidenreich, B. and Labiouse, V.: Small-scale experimental study of rockfall impacts on granular slopes, Italian Geotechnical Journal-RIG, 2, 80-91, 2004.

Hutchinson, J. N. and Bhandari, R. H.: Undrained loading, a fundamental mechanism of mudflows and other mass movements, Geotechnique, 21, 353-358, 1971.

Iovine, G., Di Gregorio, S., and Lupiano, V.: Debris-flow susceptibility assessment through cellular automata modeling: an example from 15-16 December 1999 disaster at Cervinara and San Martino Valle Caudina (Campania, southern Italy), Nat. Hazards Earth Syst. Sci., 3, 457-468, doi:10.5194/nhess-3-4572003, 2003.

Iovine, G., D’Ambrosio, D., and Di Gregorio, S.: Applying genetic algorithms for calibrating a hexagonal cellular automata model for the simulation of debris flows characterised by strong inertial effects, Geomorphology, 66, 287-303, 2005.

Iverson, R. M., Reid, M. E, and LaHusen, R. G.: Debris-flow mobilization from landslides, Annu. Rev. Earth Pl. Sc., 25, 85-138, 1997. 
Olivares, L. and Picarelli, L.: Modelling of flowslides behaviour for risk mitigation, Proc. Int. Conf. "Physical Modelling in Geotechnics”, General Report, Hong Kong, China, 1, 99-113, 2006.

Palmstrom, A.: Measurements of and Correlations between Block Size and Rock Quality Designation (RQD), Tunn. Undergr. Sp. Tech., 20(4), 362-377, 2005.

Paronuzzi, P.: Rockfall-induced block propagation on a soil slope, northern Italy, Environ. Geol., 58, 1451-1466, 2009.

Picarelli, L.: Discussion on "A rapid loess flowslide triggered by irrigation in China" by Zhang, D., Wang, G., Luo, C., Chen, J. and Zhou, Y., Landslides J., Online first, doi:10.1007/s10346010-0196-x, available at: http://www.springerlink.com/content/ 110832/?k=picarelli (last access: 7 June 2010), 2010.

Regione Campania: Dati meteorologici rilevati dalle stazioni automatiche della rete agrometeorologica regionale. Dati giornalieri, available at: http://www.sito.regione.campania.it/agricoltura/ meteo/agrometeo.htm (last access: 7 June 2010), 2009 (in Italian).

Richards, L. R.: Rockfall protection: a review of current analytical and design methods, Proc. 2th Conf. "Meccanica ed Ingegneria delle Rocce (MIR)”, Politecnico di Torino, 13, 1-13, 1988.
Rocscience Inc.: ROCFALL v. 4.0, Statistical analysis of rockfalls, Software tools for rock and soil, Toronto, Ontario, Canada, available at: http://www.rocscience.com/products/RocFall.asp (last access: 7 June 2010), 2002.

Sassa, K., Fukuoka, H., and Wang, F. W.: Mechanism and risk assessment of landslide triggered-debris flows: lesson from the 1996.12.6 Otari debris flow disaster, Nagano, Japan, in: Proc. Int. Workshop on Landslide Risk Assessment, edited by: Cruden, D. M. and Fell, R., Honolulu, 347-356, 1997.

Sassa, K., Fukuoka, H., Wang, G., and Ishikawa, N.: Undrained dynamic-loading ring-shear apparatus and its application to landslide dynamics, Landslides J., 1, 7-19, 2004, doi:10.1007/s10346-003-0004-y.

Terribile, F., Basile, A., di Gennaro, A., Aronne, G., Buonanno, M., De Mascellis, R., Vingiani, S., and Malucelli, F.: The soils of the landslides of Sarno and Quindici, Proc. Conf. "Cost Action 622", edited by: Terribile, F. and Adamo, P., Napoli, 10-23, 1999.

Wang, B. and Cavers, S. D.: A simplified approach for rockfall ground penetration and impact stress calculations, Landslides J., 5, 305-310, doi:10.1007/s10346-008-0123-6, 2008. 